DOI: $10.1515 / 1 \mathrm{pts}-2016-0021$

SOLID STATE PHYSICS

\title{
PRODUCTION OF ZnO AND CdO-ZnO THIN FILMS BY EXTRACTION- PYROLYTIC METHOD
}

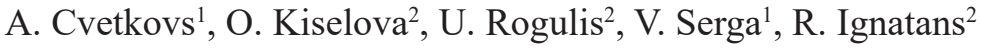 \\ ${ }^{1}$ Institute of Inorganic Chemistry, Riga Technical University, 34 Miera Str., \\ Salaspils, LV-2169, LATVIA \\ E-mail: antonzweig@hotmail.lv
}

${ }^{2}$ Institute of Solid State Physics, University of Latvia, 8 Kengaraga Str., LV-1063, LATVIA

The extraction-pyrolytic method has been applied to produce the $\mathrm{ZnO}$ and $\mathrm{CdO}-\mathrm{ZnO}$ thin films on glass and quartz glass substrates. According to $\mathrm{X}$ ray diffraction measurements, the $\mathrm{ZnO}$ and $\mathrm{CdO}$ phases have been produced with an average size of crystallites about $8-42 \mathrm{~nm}$ in the films. The thickness of the layers measured by a profilometer has been up to $150 \mathrm{~nm}$. The surface morphology measurements show that the surface of the films may be rough and non-continuous. The SEM results confirm the dependence between the preparation procedure and the quality of the thin film.

Keywords: $\mathrm{CdO}-\mathrm{ZnO}$ thin films, extraction-pyrolytic method, surface morphology, X-ray diffraction.

\section{INTRODUCTION}

Zinc oxide $\mathrm{ZnO}$ is an n-type semiconductor. Due to its crystalline structure parameters, wide band gap (approximately $3.7 \mathrm{eV}$ at room temperature), high exciton bound energy (60 meV) and possibilities to embed several impurities, $\mathrm{ZnO}$ has good optical, electrical, piesoelectrical and magnetic properties [1]. The above-mentioned properties can be changed by adding appropriate amounts of impurities or by alloying $\mathrm{ZnO}$ with other materials. As an example, the band gap of the pure $\mathrm{ZnO}$ of 3.37 $\mathrm{eV}$ could be increased up to $7.8 \mathrm{eV}$ by adding the $\mathrm{MgO}$ [2], or decreased to $2.3 \mathrm{eV}$ by adding the $\mathrm{CdO}[3]$. $\mathrm{ZnO}$ serves as important material with various applications in production of photodetectors, light diodes, biosensors, solar batteries, etc. [1], [4]-[8].

$\mathrm{CdO}-\mathrm{ZnO}$ thin films can be produced by several known technologies, such as chemical vapour deposition, "sol-gel" technique, laser ablation, radio-frequency and DC magnetron sputtering methods [9]-[14]. Each method has advantages and disad- 
vantages in terms of production procedures, equipment costs and resulting product properties; therefore, the development of new semiconductor production methods remains challenging.

The aim of the present research is to produce the thin films of $\mathrm{CdO}-\mathrm{ZnO}$ by the extraction-pyrolytic method (EPM) [14]. Comparing with other production techniques of thin films the EPM has several advantages. In case of using the EPM vacuum or high pressure, high electrical and magnetic fields, low or high temperatures are not necessary. This technology is simple and corresponds to the ecological standards. In principle, the EPM allows varying and optimising the composition, structure and properties of composite materials [15].

\section{EXPERIMENTAL PROCEDURE}

In order to produce the thin layers of $\mathrm{ZnO}$ and $\mathrm{CdO}-\mathrm{ZnO}$, the cadmium and zinc extracts were prepared. Zinc and cadmium were extracted from chloride solutions by the caproic acid without use of organic solvents, previously adding the sodium hydroxide solution in stoichiometric proportions. In order to remove the sodium ions from the organic phase, the extracts were flushed 3 times with newly prepared zinc chloride or cadmium chloride solutions. The extraction of the metal cations occurs according to the cation exchange mechanism as shown by the following reaction:

$$
M e_{(w)}^{n+}+n H R_{(o)} \rightarrow \operatorname{MeR}_{n(o)}+n H_{(w)}^{+},
$$

where $w$ refers to the water phase and $o$ - to the organic phase.

In order to determine the exact concentration of cadmium in the cadmium extract, in a platinum crucible appropriate volume of the extract was heated to $600{ }^{\circ} \mathrm{C}$ and held at this temperature for 30 minutes. The exact mass of the produced $\mathrm{CdO}$ and the concentration of the cadmium extract were calculated. The concentration of cadmium extract was found to be $0.31 \mathrm{~mol} / \mathrm{L}$.

In order to determine the exact concentration of zinc in the zinc extract, in a platinum crucible known volume of cadmium extract was added to an appropriate volume of zinc extract and the prepared mixture of extracts was heated to $600{ }^{\circ} \mathrm{C}$ (in muffle furnace SNOL 8,2/1100 L "UMEGA") and kept at this temperature for 30 minutes. In parallel, the procedure was repeated with the mixture of known volume of cadmium acetate dihydrate solution in ethanol with known concentration and known volume of zinc extract. The ratio between zinc and cadmium in the produced samples was determined by using the EDAX Eagle III Micro-XRF elemental analyser. The found ratios were used to calculate the concentration of zinc extract. Two independent calculations of the concentration of zinc extract gave the same results. The concentration of zinc extract was found to be $0.048 \mathrm{~mol} / \mathrm{L}$.

In additional, the solution of the cadmium acetate in ethanol with a concentration of $0.048 \mathrm{~mol} / \mathrm{L}$ was prepared. In order to produce thin films with different compositions, the prepared organic extracts and cadmium acetate solutions were mixed in different proportions. Extracts and their solutions were additionally diluted with caproic acid and ethanol. Defined volumes of prepared organic solutions were 
applied on the glass or the quartz glass substrates. The substrates were previously treated by a $10 \% \mathrm{NaOH}$ solution, washed in hot water, dried and treated with dichloroethane in an ultrasonic bath. After the evaporation of the solvent, the samples were heated under constant heating rate $\left(\mathrm{v}_{\text {heat. }}\right)$ from room temperature to the thermal treatment temperature $\left(\mathrm{T}_{\text {ann. }}\right)$ and held at this temperature for a definite time $\left(\mathrm{t}_{\mathrm{ann}}\right)$. Before the thermal treatment at high temperatures, the samples were dried at room temperature. This cycle of the application of organic precursor and thermal treatment in air was repeated several times. The conditions of the process are shown in Table 1.

The XRD patterns were obtained by a PANalytical X'Pert PRO spectrometer at the wavelength of $1.542 \AA\left(\mathrm{Cu} \mathrm{K}_{\alpha}\right)$. In order to calculate the mean size of crystallites, preliminary processing of the resulting X-ray diffraction data was performed by using Origin software. For the determination of the size of crystallites $(\tau)$, the Scherrer equation was used:

$$
\tau=\frac{K \lambda}{\beta \cos \theta},
$$

where $K$ is a dimensionless shape factor with a value of about 0.94 , but varies with the actual shape of the crystallite; $\lambda$ is the X-ray wavelength; $\beta$ is the line broadening at half the maximum intensity (FWHM), after subtracting the instrumental line broadening, in radians, which was calculated by using peak shape approximation with the Pseudo-Voigt function; $\theta$ is the Bragg angle.

The thickness-profile measurements of the thin films were performed by a Vecco Dektak 150 Surface Profiler profilometer. The stylus radius was around 12.5 $\mu \mathrm{m}$ and the stylus force equalled $0.03-3 \mathrm{mg}$. The surface morphology of the thin films was evaluated by scanning electron microscopy (SEM). Secondary electrons and backscattered electrons were detected.

Table 1

Thin Film Preparation Conditions (I - Zinc Extract, II - Cadmium Extract, III - Cadmium Acetate in Ethanol)

\begin{tabular}{|c|c|c|c|c|c|}
\hline $\begin{array}{l}\text { Abbreviation } \\
\text { of the thin film } \\
\text { and its expect- } \\
\text { ed chemical } \\
\text { composition }\end{array}$ & $\begin{array}{l}\text { Type of used } \\
\text { substrate and } \\
\text { the covered } \\
\text { area of sub- } \\
\text { strate, } \mathrm{cm}^{2}\end{array}$ & $\begin{array}{l}\text { Total number } \\
\text { of the applica- } \\
\text { tion-thermal } \\
\text { treatment } \\
\text { cycles }\end{array}$ & $\begin{array}{l}\text { Composition } \\
\text { of the subli- } \\
\text { mated organic } \\
\text { solution }\end{array}$ & $\begin{array}{l}\text { Volume of the } \\
\text { sublimated } \\
\text { precursor solu- } \\
\text { tion, } \mathrm{mL}\end{array}$ & $\begin{array}{l}\text { Thermal treat- } \\
\text { ment condi- } \\
\text { tions }\end{array}$ \\
\hline $\begin{array}{l}\mathbf{A}^{*} \\
(\mathrm{ZnO})\end{array}$ & Glass (19.5) & 1 & precursor I & 0.82 & $\begin{array}{c}1 . \mathrm{v}_{\text {heat }}=7^{\circ} \mathrm{C} / \\
\min , \mathrm{T}_{\text {ann. }}=300 \\
{ }^{\circ} \mathrm{C}, \mathrm{t}_{\text {ann. }}=0 \mathrm{~min} \\
2 . \mathrm{T}_{\text {ann. }}=350{ }^{\circ} \mathrm{C} \text {, } \\
\mathrm{t}_{\text {ann. }}=30 \mathrm{~min}\end{array}$ \\
\hline $\begin{array}{l}\text { B } \\
(\mathrm{CdO} \cdot 7 \mathrm{ZnO})\end{array}$ & Glass (19.5) & 5 & $\begin{array}{c}\text { mixture of } \\
\text { precursor I, } \\
\text { precursor III } \\
\text { and caproic } \\
\text { acid in volume } \\
\text { proportion of } \\
1: 0.147: 1\end{array}$ & $\begin{array}{c}0.16 \text { (cycles } \\
1-2) \\
0.32 \text { (cycles } \\
3-5)\end{array}$ & $\begin{array}{c}\mathrm{v}_{\text {heat. }}=15^{\circ} \mathrm{C} / \\
\text { min }(\text { cycles } \\
1-5), \mathrm{T}_{\text {ann. }}=350 \\
{ }^{\circ} \mathrm{C}(\text { cycles } \\
1-4), \mathrm{T}_{\text {ann. }}=400 \\
{ }^{\circ} \mathrm{C}(\text { cycle } 5), \\
\mathrm{t}_{\text {ann. }}=5 \text { min } \\
(\text { cycles } 1-5)\end{array}$ \\
\hline
\end{tabular}




\begin{tabular}{|c|c|c|c|c|c|}
\hline $\begin{array}{l}\mathbf{C} \\
(\mathrm{CdO} \cdot 7 \mathrm{ZnO})\end{array}$ & $\begin{array}{l}\text { Quartz glass } \\
\quad(19.6)\end{array}$ & 5 & $\begin{array}{c}\text { mixture of } \\
\text { precursor I, } \\
\text { precursor III } \\
\text { and caproic } \\
\text { acid in volume } \\
\text { proportion of } \\
1: 0.147: 1\end{array}$ & $\begin{array}{c}0.16 \text { (cycles } \\
1-2 \text { ) } \\
0.32 \text { (cycles } \\
3-5 \text { ) }\end{array}$ & $\begin{array}{c}\mathrm{v}_{\text {heat. }}=15^{\circ} \mathrm{C} / \\
\text { min }(\text { cycles } \\
1-5), \mathrm{T}_{\text {ann. }}=350 \\
{ }^{\circ} \mathrm{C}(\text { cycles } \\
1-4), \mathrm{T}_{\text {ann. }}=400 \\
{ }^{\circ} \mathrm{C}(\text { cycle } 5), \\
\mathrm{t}_{\text {ann. }}=5 \text { min } \\
\text { (cycles 1-5) }\end{array}$ \\
\hline $\begin{array}{l}\text { D } \\
(\mathrm{CdO} \cdot 75 \mathrm{ZnO})\end{array}$ & $\begin{array}{l}\text { Quartz glass } \\
\quad(19.6)\end{array}$ & 8 & $\begin{array}{c}\text { mixture of } \\
\text { precursor I, } \\
\text { precursor III } \\
\text { and caproic } \\
\text { acid in volume } \\
\text { proportion of } \\
\text { 1:0.0133:1 }\end{array}$ & $\begin{array}{c}0.15 \text { (cycles } \\
1-8)\end{array}$ & $\begin{array}{c}\mathrm{v}_{\text {heat. }}=15^{\circ} \mathrm{C} / \\
\text { min }(\text { cycles } \\
1-8), \mathrm{T}_{\text {ann. }}=350 \\
{ }^{\circ} \mathrm{C}(\text { cycles } \\
1-7), \mathrm{T}_{\text {ann }}=400 \\
{ }^{\circ} \mathrm{C}(\text { cycle } 8), \\
\mathrm{t}_{\text {ann. }}=5 \mathrm{~min} \\
(\text { cycles } 1-7), \\
\mathrm{t}_{\text {ann. }}=30 \text { min } \\
\text { (cycle } 8)\end{array}$ \\
\hline $\begin{array}{l}\mathbf{E} \\
(4 \mathrm{CdO} \cdot 7 \mathrm{ZnO})\end{array}$ & $\begin{array}{l}\text { Quartz glass } \\
(19.6)\end{array}$ & 8 & $\begin{array}{c}\text { mixture of } \\
\text { precursor I, } \\
\text { precursor III } \\
\text { and caproic } \\
\text { acid in volume } \\
\text { proportion of } \\
1: 0.57: 1\end{array}$ & $\begin{array}{c}0.19 \text { (cycles } \\
1-8 \text { ) }\end{array}$ & $\begin{array}{c}\mathrm{v}_{\text {heat. }}=15^{\circ} \mathrm{C} / \\
\text { min }(\text { cycles } \\
1-8), \mathrm{T}_{\text {ann. }}=350 \\
{ }^{\circ} \mathrm{C}(\text { cycles } \\
1-7), \mathrm{T}_{\text {ann. }}=400 \\
{ }^{\circ} \mathrm{C}(\text { cycle } 8), \\
\mathrm{t}_{\text {ann. }}=5 \mathrm{~min} \\
(\text { cycles } 1-7), \\
\mathrm{t}_{\text {ann. }}=60 \text { min } \\
\text { (cycle } 8)\end{array}$ \\
\hline $\begin{array}{l}\mathbf{F} \\
(\mathrm{CdO})\end{array}$ & $\begin{array}{l}\text { Quartz glass } \\
\text { (13.4) }\end{array}$ & 8 & $\begin{array}{c}\text { mixture of } \\
\text { precursor II } \\
\text { and caproic } \\
\text { acid in volume } \\
\text { proportion of } \\
\text { 1:5.25 }\end{array}$ & $\begin{array}{c}0.10 \text { (cycles } \\
1-8)\end{array}$ & $\begin{array}{c}\mathrm{v}_{\text {heat. }}=15^{\circ} \mathrm{C} / \\
\text { min }(\text { cycles } \\
1-8), \mathrm{T}_{\text {ann. }}=350 \\
{ }^{\circ} \mathrm{C}(\text { cycles } \\
1-7), \mathrm{T}_{\text {ann }}=400 \\
{ }^{\circ} \mathrm{C}(\text { cycle } 8), \\
\mathrm{t}_{\text {ann. }}=5 \mathrm{~min} \\
(\text { cycles } 1-7), \\
\mathrm{t}_{\text {ann. }}=30 \text { min } \\
\text { (cycle } 8)\end{array}$ \\
\hline $\begin{array}{l}\mathbf{G} \\
(\mathrm{CdO} \cdot 7 \mathrm{ZnO})\end{array}$ & $\begin{array}{l}\text { Quartz glass } \\
(13.4)\end{array}$ & 8 & $\begin{array}{c}\text { mixture of } \\
\text { precursor I, } \\
\text { precursor II } \\
\text { and caproic } \\
\text { acid in volume } \\
\text { proportion of } \\
\text { 1:0.022:1.12 }\end{array}$ & $\begin{array}{c}0.10 \text { (cycles } \\
1-8)\end{array}$ & $\begin{array}{c}\mathrm{v}_{\text {heat. }}=15^{\circ} \mathrm{C} / \\
\text { min }(\text { cycles } \\
1-8), \mathrm{T}_{\text {ann. }}=350 \\
{ }^{\circ} \mathrm{C}(\text { cycles } \\
1-7), \mathrm{T}_{\text {ann }}=400 \\
{ }^{\circ} \mathrm{C}(\text { cycle } 8), \\
\mathrm{t}_{\text {ann. }}=5 \mathrm{~min} \\
(\text { cycles } 1-7), \\
\mathrm{t}_{\text {ann. }}=30 \text { min } \\
\text { (cycle } 8)\end{array}$ \\
\hline
\end{tabular}

*thermal treatment performed by inserting the sample in the preheated chamber 


\section{RESULTS AND DISCUSSION}

XRD patterns of the $\mathrm{ZnO}$ and $\mathrm{CdO}-\mathrm{ZnO}$ thin film are shown in Figs. 1-4.
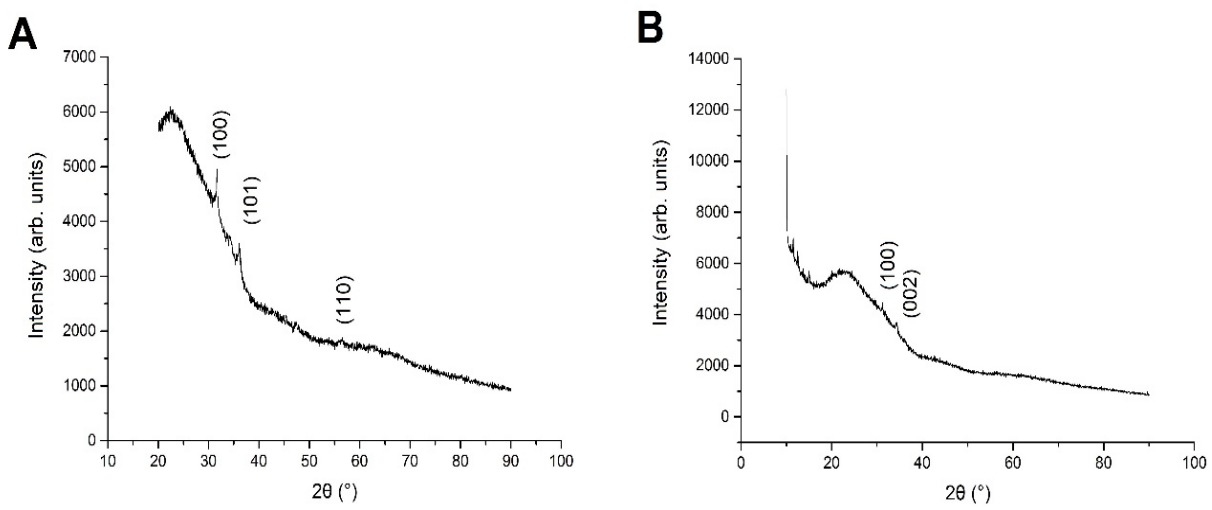

Fig. 1. XRD patterns of films $\mathbf{A}$ and $\mathbf{B}$.

For the $\mathrm{ZnO}$ thin film on the glass substrate, several diffraction maxima were observed at (100), (002), (101), (012) and (110) crystallographic plane orientations. For the thin film B on the glass substrate, the (100) and (002) crystallographic plane orientations could be observed; however, the diffraction peaks were less intense compared to the diffraction peaks on the $\mathrm{ZnO}$ diffractogram.
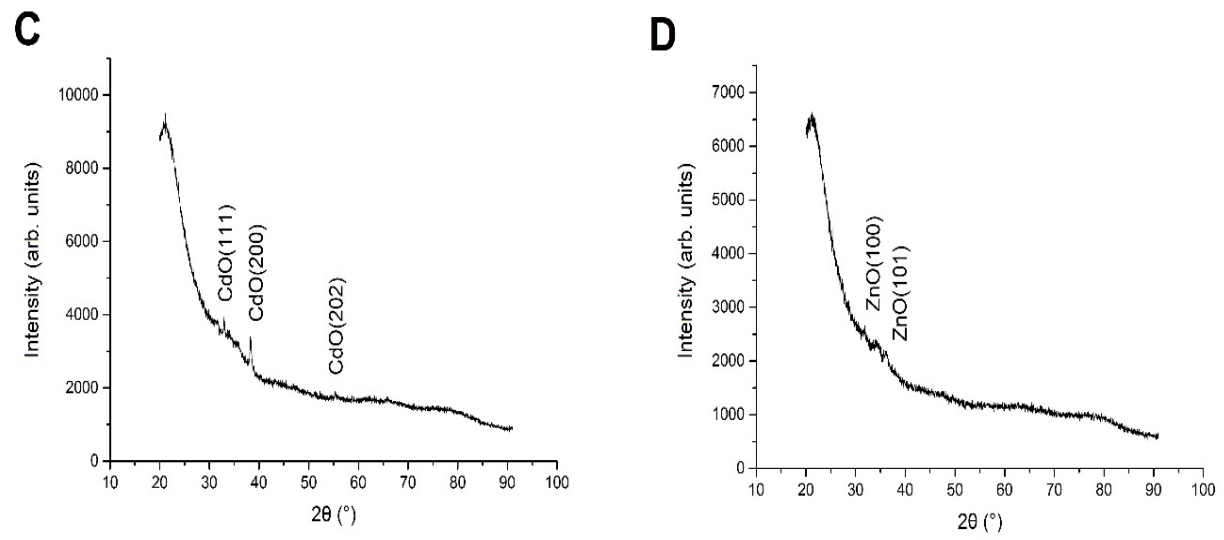

Fig. 2. XRD patterns of films $\mathbf{C}$ and $\mathbf{D}$.

In contrast to the thin film $\mathbf{B}$ on the glass substrate, on the diffractogram of thin film $\mathbf{C}$, which was produced on the quartz glass substrate, additional diffraction maxima at crystallographic plane orientations (111), (200) and (202) could be observed. By comparing the diffraction maxima of all thin films with the data of the Crystallography Open Database [16]-[18], it turned out that all the diffraction maxima (100), (002) and (101) corresponded to the hexagonal wurtzite $\mathrm{ZnO}$ struc- 
ture. However, the (111), (200) and (202) diffraction maxima corresponded to the cubic $\mathrm{CdO}$ structure (creation of mixed $\mathrm{ZnO}$ and $\mathrm{CdO}$ crystallographic phases was not observed). Taking into account that all diffraction maxima of the thin films were observed at several orientations of crystallographic planes, we concluded that our investigated thin films had polycrystalline structures. Creation of $\mathrm{Cd}_{\mathrm{x}} \mathrm{Zn}_{1-\mathrm{x}} \mathrm{O}$ crystallographic phase was possible only in case of sample $\mathbf{B}$ because of shifting of the diffraction peak (100) towards lower angles $\quad\left(\mathrm{Cd}_{\mathrm{x}} \mathrm{Zn}_{1-\mathrm{x}} \mathrm{O}-\right.$ solid solution of zinc oxide and cadmium oxide; $\mathrm{xCdO} \cdot \mathrm{yZnO}$ - a mixture containing several phases, $\mathrm{x}$ and $\mathrm{y}$ are moles). In case of sample $\mathbf{D}$, the shifting of $\mathrm{ZnO}$ diffraction peaks was not observed.
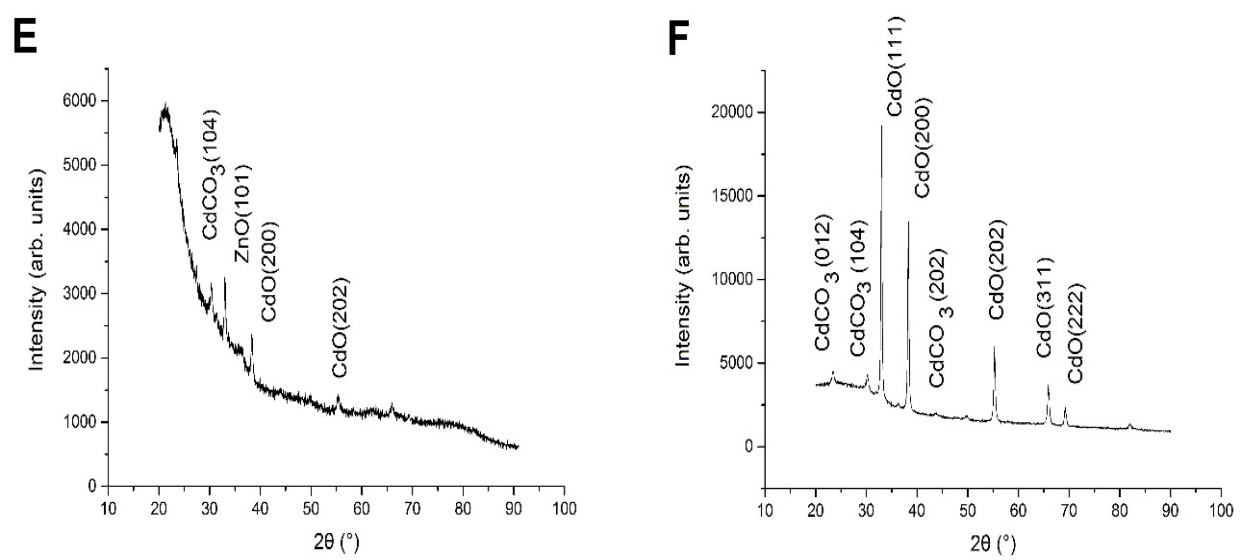

Fig. 3. XRD patterns of films $\mathbf{E}$ and $\mathbf{F}$.

On the diffractograms of samples $\mathbf{E}, \mathbf{F}$ and $\mathbf{G}$ intensive diffraction maxima are visible, which correspond to the otavite $\mathrm{CdCO}_{3}$. The presence of $\mathrm{CdO}$ phase with cubic structure in the samples is also confirmed. The presence of mixed $\mathrm{Cd}_{\mathrm{x}} \mathrm{Zn}_{1-\mathrm{x}} \mathrm{O}$ crystallographic phase is not confirmed by XRD.

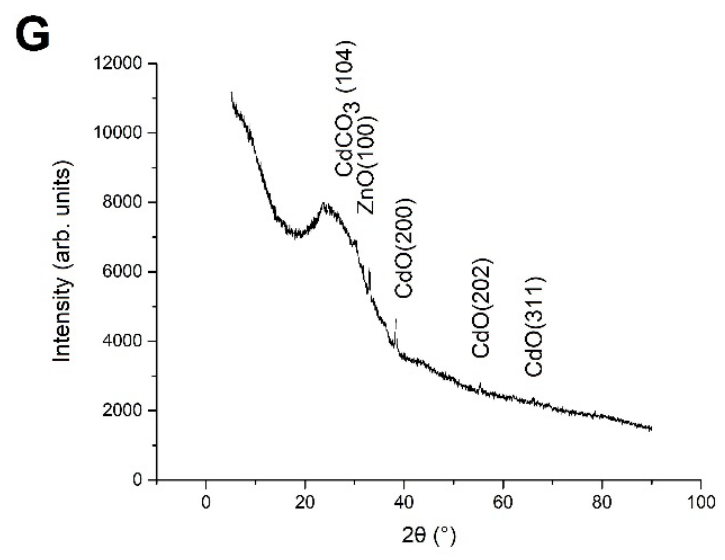

Fig. 4. XRD pattern of film $\mathbf{G}$. 
In air the second reaction is possible:

$$
\mathrm{CdO}+\mathrm{CO}_{2} \stackrel{120-140^{\circ} \mathrm{C}}{\longrightarrow} \mathrm{CdCO}_{3} \text {. }
$$

The process of the formation of cadmium carbonate after decomposition of organic precursors is also possible, but the process described by the above-mentioned reaction has a higher chance to occur. The process of the decomposition of organic precursors should be performed and investigated in inert atmosphere at higher temperatures. Thin films produced after thermal treatment should be cooled in inert atmosphere to avoid the interaction with carbon dioxide.

The calculated average size of crystallites in the $\mathrm{ZnO}$ thin film on the glass substrate is $8-39 \mathrm{~nm}$. For the thin films with chemical composition of $\mathrm{CdO} \cdot 7 \mathrm{ZnO}$, the size of the crystallites of $\mathrm{ZnO}$ phase is $15-19 \mathrm{~nm}$ and 8-14 $\mathrm{nm}$ for the glass and quartz substrates respectively, and the sizes of $\mathrm{CdO}$ crystallites are $8-42 \mathrm{~nm}$. It could be observed that the size of the $\mathrm{ZnO}$ crystallites diminished in presence of the $\mathrm{CdO}$ phase in the sample. The intensities of the diffraction peaks of $\mathrm{ZnO}$ phase became also weaker. It is possible that the presence of cadmium affects the formation of $\mathrm{ZnO}$ phase with high crystallinity.
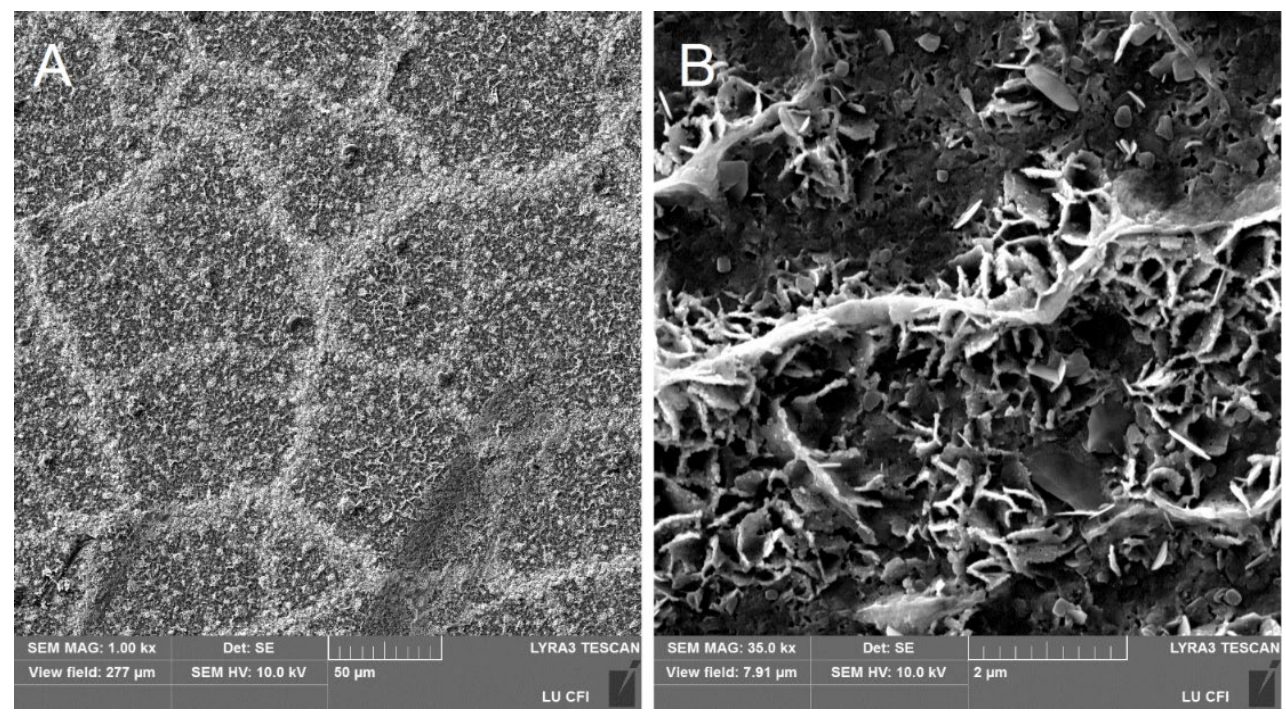

Fig. 5. SEM microphotograph of sample A (A - at lower magnification; B - at higher magnification).

The surfaces of the samples $\mathbf{A}$ and $\mathbf{C}$ are shown in Fig. 5 and Fig. 6, respectively. The surface of sample $\mathbf{A}$ has a lower quality and is rougher.

The bad quality of the thin film A can be explained by the intensive gas release process when a larger amount of organic precursor is decomposed (see Table 1). The uniform organic layer is not always formed on the substrate after the evaporation of diluent (after thermal treatment non-continuous oxide film is produced); hence, the additional cycle of the application of organic precursor and thermal treatment is necessary to produce a more uniform oxide film. In addition, the temperature of 350 ${ }^{\circ} \mathrm{C}$ may not be sufficient for the total decomposing of organic precursor, so some amorphous phases may remain in the thin film A. The results of analysis of SEM 
microphotograph are in a good correspondence with the results of profile measurements of the thin films.
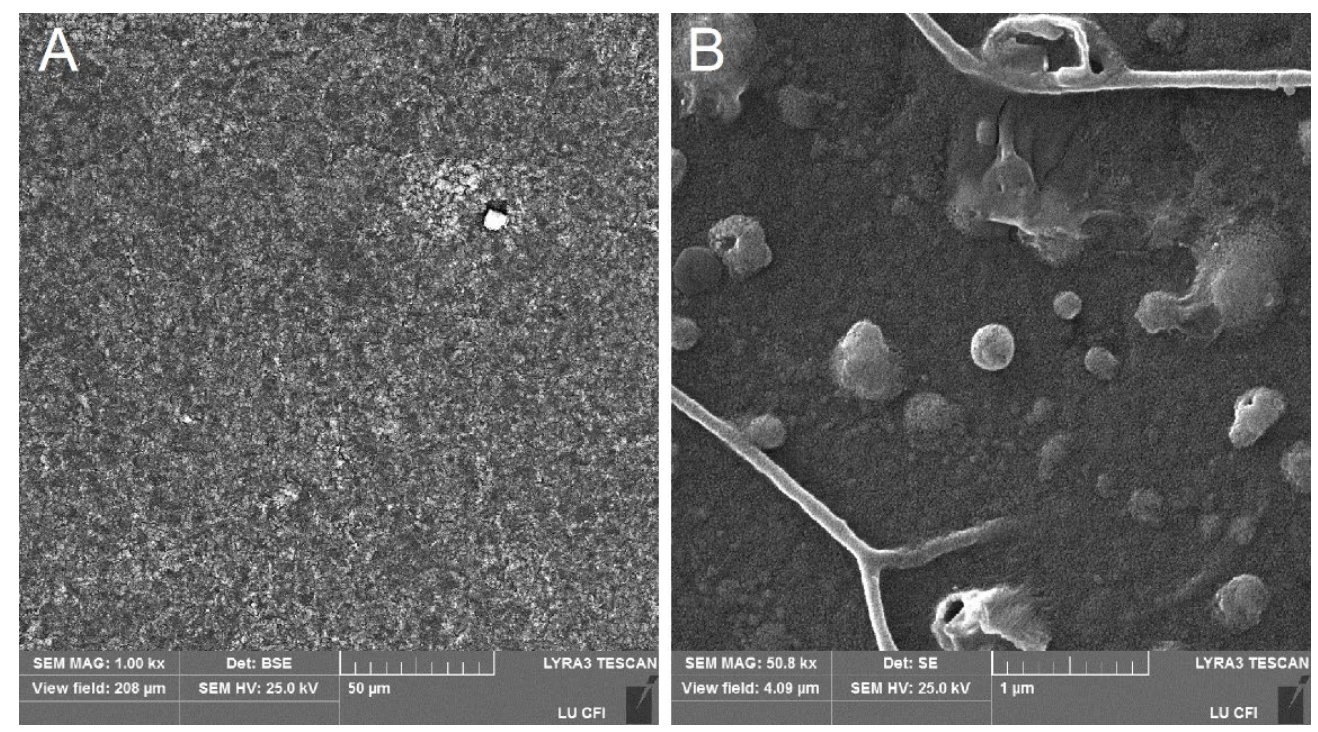

Fig. 6. SEM microphotograph of sample $\mathbf{C}$ (A - at lower magnification; B - at higher magnification).

Measurements of the thickness of thin films showed that the thin $\mathrm{ZnO}$ film on the glass substrate was $150 \mathrm{~nm}$ thick, whereas the thickness of the thin films with chemical composition of $\mathrm{CdO} \cdot 7 \mathrm{ZnO}$ on both the glass and the quartz glass substrate equalled approximately $100 \mathrm{~nm}$. It was established during the production of thin films that the thickness of the resulting film could be controlled by varying the volume of applied organic solution.

\section{CONCLUSIONS}

$\mathrm{ZnO}$ and $\mathrm{CdO}-\mathrm{ZnO}$ thin films have been produced for the first time by the extraction-pyrolytic method. The produced $\mathrm{CdO}$ and $\mathrm{ZnO}$ layers are polycrystalline with an average size of crystallites about 8-42 $\mathrm{nm}$. The formation of the cadmium carbonate phase in the $\mathrm{CdO}$ containing films has been confirmed. The resulting quality of thin film depends on its production technology.

\section{ACKNOWLEDGEMENTS}

The present research has been supported by the Latvian State Research Programme on Innovative Materials IMIS2 (2014-2017). Technical assistance with SEM measurements provided by Karlis Kundzins at the Institute of Solid State Physics, University of Latvia, is acknowledged. Technical assistance with elemental analysis provided by Linards Skuja at the Institute of Solid State Physics, University of Latvia, is also acknowledged. 


\section{REFERENCES}

1. Ozgur, U., Alivov, Ya. I., Liu, C., Teke, A., Reshchikov, M. A., Dogan, S., Avrutin, V., Cho, S.-J., and Morkoc, H. (2005). A comprehensive review of $\mathrm{ZnO}$ materials and devices. J. Appl. Phys. 98, 041301.

2. Ma, D.W., Ye, Z.Z., Lu, H.M., Huang, J.Y., Zhao, B.H., Zhu, L.P., and Zhang, H.J. (2004). Sputtering deposited ternary $\mathrm{Zn}_{1-\mathrm{x}} \mathrm{Cd}_{\mathrm{x}} \mathrm{O}$ crystal films on $\mathrm{Si}(111)$ substrates. Thin Solid Films. 461, 250-255.

3. Wei, M., Boutwell, R.C., Mares, J.W., Scheurer, A., and Schoenfeld, W.V. (2011). Bandgap engineering of sol-gel synthesized amorphous $\mathrm{Zn}_{(1-x)} \mathrm{Mg}_{(\mathrm{x})} \mathrm{O}$ films. Appl. Phys. Lett. 98, 261913.

4. Bae, H.S., and Seogil, I. (2004). Ultraviolet detecting properties of ZnO-based thin film transistors. Thin Solid Films. 469-470, 75-79.

5. Chou, Sh.M., Teoh, L.G., Lai, W.H., Su, Y.H., and Hon, M.H. (2006). ZnO:Al thin film gas sensor for detection of ethanol vapor. Sensors. 6, 1420-1427.

6. Zhao, Zh., Lei, W., Zhang, X., Wang B., and Jiang, H. (2010). ZnO-Based Amperometric Enzyme Biosensors. Sensors. 10, 1216-1231.

7. Chu, Sh., Olmedo, M., Yang, Zh., Kong, J., and Liu, J. (2008). Electrically pumped ultraviolet $\mathrm{ZnO}$ diode lasers on Si. Appl. Phys. Lett. 93, 181106.

8. Li, K., Li, Y., and Xue, D. (2011). Band gap prediction of alloyed semiconductors. Funct. Mat. Lett. 4, 217-219.

9. Coutt, T.J., Perkins, J.D., Ginley, D.S., and Mason, T.O. (1999). Transparent conducting oxides: status and opportunities in basic research. In 195th Meeting of the Electrochemical Society, 2-6 May 1999. Seattle, Washington.

10. Lee, J.H., and Park, B.O. (2003). Transparent conducting ZnO:Al, In and Sn, thin films deposited by the sol-gel method. Thin Solid Films. 426, 94-99.

11. Hiramatsu, M., Imaeda, K., Horio, N., and Nawata, M. (1998). Transparent conducting $\mathrm{ZnO}$ thin films prepared by $\mathrm{XeCl}$ excimer laser ablation. J. Vac. Sci. Technol. A. 16, 669-673.

12. Lee, J., Li, Z., Hodgson, M., Metson, J., Asadov, A., and Gao, W. (2004). Structural, electrical and transparent properties of $\mathrm{ZnO}$ thin films prepared by magnetron sputtering. Curr. Appl. Phys. 4 (2-4), 398-401.

13. Konstantinidis, S., Hemberg, A., Dauchot, J.P., and Hecq, M. (2007). Deposition of zinc oxide layers by high-power impulse magnetron sputtering. J. Vac. Sci. Technol. B. 25, 19-21.

14. Fan, J.C., Sreekanth, K.M., Xie, Z., Chang, S.L., and Rao, K.V. (2013). p-Type ZnO materials: Theory, growth, properties and devices Pro. Mater. Sci. 58, 874-985.

15. Khol'kin, A.I., and Patrusheva, T.N. (2006). Extraction-Pyrolytic Method: Production of Functional Oxide Materials, Moscow: KomKniga.

16. Grazulis, S., Daskevic, A., Chateiger, D., Lutterotti, L., Quios, M., Serebryanaya, N. R., Mock, P., Downs, R. T., and Le Bail, A. (2012). Crystallography Open Database (COD): an open-access collection of crystal structures and platform for world-wide collaboration. Nuc. Acids Res. 40, 420-427.

17. Grazulis, S., Chateigner, D., Downs, R. T., Yokochi, A. T., Quiros, M., Lutterotti, L., Manakova, E., Butkus, J., Moeck, P., and Le Bail, A. (2009). Crystallography Open Database - An open-access collection of crystal structures. J. Appl. Cryst. 42, 726-729.

18. Downs, R. T., and Hall-Wallace, M. (2003). The American Mineralogist Crystal Structure Database. Am. Mineral. 88, 247-250. 


\section{ZnO UN CdO-ZnO PLĀNO KĀRTIN̦U IEGŪŠANA AR EKSTRAKCIJAS- PIROLITTISKO METODI}

A. Cvetkovs, O. Kiseḷova, U. Rogulis, V. Serga, R. Ignatāns

Kopsavilkums

Darbā ZnO in CdO-ZnO plāno kārtiņu iegūšanai uz stikla un kvarca stikla pamatnēm tika izmantota ekstrakcijas-pirolītiskā metode. Rentgenstaru difrakcijas dati norāda uz $\mathrm{ZnO}$ un $\mathrm{CdO}$ kristālisko fāžu veidošanos ar vidējo kristalītu izmēru 8-42 nm kārtin̄ās. Ar profilometru noteiktais iegūto kārtiņu biezums sasniedza 150 nm. Virsmas morfologijijas mērījumi parāda, ka kārtinas var būt nelīdzenas un var pilnīgi nepārklāt pamatnes virsmu. Mainot kārtiņu iegūšanas tehnoloǵiju, var būtiski ietekmēt pārklājumu kvalitāti. Par to liecina iegūtās kārtiṇu SEM mikrofotogrāfijas.

02.11.2015. 